\title{
ALULDETERMINÁLT SZERKEZETEK ZÉRUS FREKVENCIÁJÚ SAJÁTMÓDJAINAK VALÓSÁGHÛ́ ÁBRÁZOLÁSA
}

\section{REALISTIC REPRESENTATION OF THE EIGENMODES OF AN UNDERDETERMINED STRUCTURE}

\author{
Kakucs András ${ }^{1}$, Popa-Müller Izolda ${ }^{2}$, Pásztor Judith ${ }^{3}$ \\ ${ }^{1}$ Sapientia-EMTE, Müszaki és Humántudományok Kar-Marosvásárhely, Gépész- \\ mérnökiTanszék,kakucs2@ms.sapientia.ro \\ ${ }^{2}$ Sapientia-EMTE, Müszaki és Humántudományok Kar-Marosvásárhely, Gépész- \\ mérnöki Tanszék, ipmuller@ms.sapientia.ro \\ ${ }^{3}$ Sapientia-EMTE, Müszaki és Humántudományok Kar-Marosvásárhely, Gépész- \\ mérnöki Tanszék,pjudit@ms.sapientia.ro
}

\begin{abstract}
This paper presents a method used in the realistic representation of the zero-frequency eigenmodes of an underdetermined structure, developed by our team. These structures are mechanisms, in fact, so this method may form the basis of a new one used in the analysis of the mechanisms.
\end{abstract}

Keywords: mechanism, eigenmode.

\section{Összefoglalás}

A dolgozat célja annak az eljárásnak a bemutatása, amelyet aluldeterminált szerkezetek zérus frekvenciájú sajátmódjainak valósághủ ábrázolására fejlesztettünk ki. Mivel e szerkezetek tulajdonképpen mechanizmusok, a bemutatott eljárást továbbfejlesztve, az, egy, a mechanizmusok pozíció-elemzésére alkalmas módszerének alapját képezheti.

Kulcsszavak: mechanizmus, sajátmód.

\section{Aluldeterminált végeselemes modellek}

Egy végeselemes-program megalkotása közben felvetődött az aluldeterminált szerkezetek felismerésének az igénye, illetve az a követelmény, hogy ha a szerkezet mégis aluldeterminált lenne, akkor ábrázoljuk annak a zérus sajátmódjait.

$\mathrm{Az}$ ilyen szerkezetek csuklós mechanizmust alkotnak, azonban annak egyszerü támaszai csuszkaként müködhetnek. A szakirodalom ajánl néhány eljárást (Csebisev, Kutzbach, Grübler), amelyek egy mechanizmus szabadságfokainak kiszámítására alkalmasok, azonban meg is jegyzi, hogy bizonyos esetekben ezek alkalmazásával téves következtetésekre juthatunk. Konkrétan: megtörténhet, hogy a szabadságfokok száma e kritériumok alapján nulla lenne és levonhatnánk azt a téves következtetést, hogy egy stabil szerkezettel van dolgunk, holott egy mechanizmussal állunk szemben. E kritériumokat tehát in- 
kább csak annak a tesztelésére használhatjuk, hogy meggyőződhessünk arról, hogy egészen biztos mechanizmussal állunk szemben, de arra nem, hogy bármely esetben biztonságosan megállapíthassuk a szerkezet stabil voltát.

A szakirodalomban sokfajta eljárás létezik a mechanizmusok pozíció-analízisére, az [1] szakirodalmi hivatkozás pl. 21, egymástól különböző alapelven nyugvó megoldást sorol fel.

Mivel eleve egy végeselemes modellezéssel foglalkozó program fejlesztéséről van szó, megpróbáltunk olyan megoldásokat keresni, amelyek a program adatstruktúrájához és jellegéhez igazodnak.

\section{Közelítés sajátvektorokkal}

Az első lehetséges és kipróbált megoldás a sajátmód-analízis lenne, mint egy újabb, huszonkettedik lehetőség. Ez az eljárás a zérus-módok kiszámítására alapoz. Amennyiben a tanulmányozott szerkezet diszkretizálása során $n$ csomóponthoz jutunk, csomópontonként pedig $n_{f}$ szabadságfokot definiálunk (két dimenzióban például az $x$ és $y$ irányú elmozdulásnak megfelelően kettőt), akkor egy összesen $N=n \cdot n_{f}$ dinamikai szabadságfokú modellhez jutunk. Ha ez egy stabil szerkezet stabil modellje, akkor annak $N$ nem-zéró frekvenciájú sajátmódja van. Ha viszont zéró sajátfrekvenciájú módokhoz jutunk, akkor azok a mechanizmust alkotó instabil szerkezet olyan mozgásformáinak felelnek meg, amikor annak szabadságfokai közül csak egyet hagyunk szabadon és a többit rögzítjük.

E módszer elönye akkor mutatkozna meg, ha amúgy is sajátmód-elemzést szeretnénk elvégezni, ugyanis ilyenkor nincs szükség külön számításokra. Van azonban egy nagy hátránya is: a sajátmód-analízis lineáris viselkedést feltételez, egy bizonyos pozícióban végzett kis amplitúdójú rezgésekről, elmozdulásokról nyújt információt, a mechanizmusok pedig a nagy elmozdulá- sok miatt geometriailag nem-lineáris szerkezetek. Erre rátevődik az a tény is, hogy a végeselemes analízisben a csomópontoknak rendszerint nincs rotációs szabadságfokuk, ami miatt az elfordulás, mint mozgásforma, csak a pontok elmozdulásainak eredményeként jöhet létre. Például, ha két dimenzióban dolgozunk és egy rögzítetlen testet tanulmányozunk, akkor annak három szabadságfoka van és, a számítások eredményeként, három zérus módhoz jutunk. E három mód sajátvektorai a csomópontok vízszintes és függőleges irányú elmozdulásaiként három mozgásformát definiálnak, azonban azokból pl. a Gram-Schmidt eljárás alkalmazásával sem nyerhetjük ki az elméletileg elvárt két merőleges irányú elmozdulás ábra síkjában történő elfordulás sajátmódokat, a rotációs szabadságfokok hiánya miatt.

\section{A merevsági mátrix módszeré- nek adaptálása}

A második, általunk kidolgozott és alkalmazott eljárás azon az észrevételen alapul, hogy az aluldeterminált szerkezet merevségi mátrixa szinguláris, inverzének kiszámítása során a fóátlóján zérók jelennek meg - mondhatjuk, hogy a rögzítetlen szabadságfokoknak megfelelö helyeken.

A szakirodalomban fellelhető egy, valószínüleg a következökben bemutatotthoz hasonlító eljárás [2] - hogy mennyire hasonló, azt nem tudjuk, mert az idézett cikk csak pénzért érhető el, tehát következzék itt a miénk, ingyen.

A merevtest-elmozdulások vizsgálata során fölösleges a diszkretizált szerkezet merevségi mátrixával dolgoznunk, ugyanis a merevtest-elmozdulás során a szerkezetet alkotó alkatrészek (a mechanizmus tagjai) nem szenvednek rugalmas alakváltozást. Ésszerübb lenne a mechanizmus tagjait egymáshoz kapcsolódó végeselemeknek tekinteni. Ezek a tagok azonban tetszőleges számú pontban illeszkednek egymáshoz és az aljzathoz, tetszőleges számú végeselem 
pedig nem létezik. Éppen ezért a szerkezetet rúdelemekre osztjuk, a következő módon: ha a mechanizmus egyik tagja $n$ csomópontban illeszkedik a többihez és az aljzathoz, akkor pl. a Delaunayalgoritmussal egy háromszöghálót építhetünk annak csomópontjaira, amelynek az élei egy determinált rácsszerkezetet definiálnak. Ha viszont nem akarunk a Delaunayhálózással bíbelődni, akkor minden csomópontot minden csomóponttal összekötve egy csillagsokszög alakú, szupradeterminált rácsos szerkezetet alkotó modellhez jutunk, bevállalva a nagyobb számú elem megjelenésével járó többlet-munkát. A modell szabadságfokainak száma nem változik meg, a mechanizmust modellező szerkezet merevségi mátrixa mindkét esetben ugyanakkora marad.

Egy mindkét végén csuklóval illeszkedő rúdelem merevségi mátrixában $k=E \cdot A / L$ formájú tagok vannak, kétdimenziós esetben például [3]:

$$
[k]=\left[\begin{array}{cccc}
k & 0 & -k & 0 \\
0 & 0 & 0 & 0 \\
-k & 0 & k & 0 \\
0 & 0 & 0 & 0
\end{array}\right]
$$

Ezek a rúdelemek ugyan egy valódi szerkezet modellezése során keletkeznek, azonban most lényegtelen a merevségük tényleges értéke, mivel a terheletlen mechanizmus mozgását vizsgáljuk. Így elfogadhatjuk pl. azt, hogy az $E \cdot A$ szorzat értéke egységnyi (a SI-ben a mértékegysége $\mathrm{N}$ lenne), $L$ pedig a rudak tényleges hossza (a csomópontok távolsága), m-ben.

A rúdelem végpontjainak koordinátáival kiszámítható annak a vízszintes tengellyel bezárt $\alpha$ szöge, amelynek $s$ szinuszával és $c$ koszinuszával meghatározható a

$$
[T]=\left[\begin{array}{cccc}
c & s & 0 & 0 \\
-s & c & 0 & 0 \\
0 & 0 & c & s \\
0 & 0 & -s & c
\end{array}\right]
$$

transzformációs mátrix, amely a rúdelemnek a globális koordináta-rendszerben érvényes

$$
\left[k^{\prime}\right]=[T]^{T} \cdot[k] \cdot[T]
$$

merevségi mátrixához vezet. A rúdelemek ilyen módon transzformált merevségi mátrixaival megkapjuk a rács-szerkezet $[K]$ merevségi mátrixát.

E mátrix $[K]^{-1}$ inverzét a Gausseliminációs módszerrel, teljes pivotálással próbáljuk meghatározni. E pivotálás során az $i$ és $j$ szabadságfokoknak megfelelö sorok és oszlopok felcserélésével az éppen normalizálni kívánt $i$ helyzetbe a föátlón levő, még nem normalizált legnagyobb $j$ elemet hozzuk be, az elvégzett csereberék számontartása mellett. E folyamat végén, ha a mátrix szinguláris volt, akkor az utolsó $m$ föátlón levő elem nulla lesz. E sorok normalizálása emiatt nem lehetséges, így a merevségi mátrix inverzét nem tudjuk kiszámítani, de erre nincs is szükség: a számunkra hasznos információ abban áll, hogy melyek azok a szabadságfokok, amelyek rögzítetlen volta miatt a szerkezetünk mechanizmusként viselkedik.

Ezután ezeket a szabadságfokokat rögzítjük: $m-1$ szabadságfok esetében zérus, a maradék szabadságfok esetében pedig a $D_{k}=\delta$ elmozdulás elöírásával, ahol $\delta$ értékét nullától kezdve fokozatosan és kis lépésekben változtatjuk a mechanizmus keresett pozícióinak megfelelően. Az elmozdulások ilyen módon történő előírásával a szerkezet determinálttá válik, az egyensúlyát pedig az

$$
\left\{\begin{array}{l}
\left\{F_{e}\right\} \\
\left\{F_{n}\right\}
\end{array}\right\}=\left[\begin{array}{ll}
{\left[K_{e n}\right]} & {\left[K_{e e}\right]} \\
{\left[K_{n e}\right]} & {\left[K_{n n}\right]}
\end{array}\right] \cdot\left\{\begin{array}{l}
\left\{D_{n}\right\} \\
\left\{D_{e}\right\}
\end{array}\right\}
$$


formában partícionált lineáris egyenletrend-

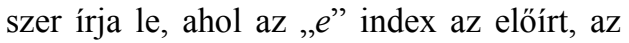
,$n$ " pedig az ismeretlen mennyiségekre vonatkozik, ahol $\left\{F_{e}\right\}$ csak zérusokat tartalmaz (mert egy terheletlen, mechanizmusként müködő szerkezet mozgásformáit vizsgáljuk) és az esetek többségében $\left\{D_{e}\right\}$

legtöbb eleme is nulla (közöttük van a $\delta$ elmozdulás is). A számítás a következő lépésekből álló ciklus ismétléséből áll, amely a nagy elmozdulásokból fakadó nemlineáris jelleg miatt szükséges:

- a végpontoknak az előző lépésben kiszámolt elmozdulásokkal aktualizált helyzetének megfelelő koordinátáival elemenként meghatározzuk az $\alpha$ szöget és azzal a $[T]$ transzformációs mátrixot, ez utóbbival pedig az elemnek az éppen aktuális helyzetében érvényes $\left[k^{\prime}\right]$ merevségi mátrixát. $\mathrm{E}$ mátrixokkal felépítjük a szerkezet $[K]$ merevségi mátrixát;

- a partícionált merevségi mátrix megfelelő tagjaival kiszámoljuk az előírt elmozdulásokból származó

$$
\left\{F^{*}\right\}=\left[K_{e e}\right] \cdot\left\{D_{e}\right\}
$$

összetevőket, amelyeket kivonunk az elöírt erők amúgy zérus $\left\{F_{e}\right\}$ vektorából. E terheléssel a

$$
-\left\{F^{*}\right\}=\left[K_{e n}\right] \cdot\left\{D_{n}\right\}
$$

egyenletrendszer megoldásával kiszámoljuk az ismeretlen $\left\{D_{n}\right\}$ elmozdulásokat;

- mivel az elmozdulások egy terheletlen, adott pozícióban rögzített mechanizmus csomópontjainak helyzetéhez kellene vezessenek, valójában az $\left\{F^{*}\right\}$ erők nullák kellene legyenek: ezek az erők csak akkor lesznek nullák, ha az adott pozícióban a mechanizmus tagjai (a rúdelemek) nem szenvedtek alakváltozást. Amennyiben $\left\{F^{*}\right\}$ tagjai nem elhanyagolhatóan kicsik, akkor a $\left\{D_{n}\right\}$ elmozdulásokkal aktualizál- juk a csomópontok helyzetét és megismételjük az iteratív folyamatot.

\section{Következtetések}

Megtörténhet, hogy egy adott pozícióban a folyamat nem konvergál: ez azt jelenti, hogy ez az elmozdulás nem kompatibilis a mechanizmus elmozdulásával, túlmutat annak valamelyik holtpontján. Ilyenkor $\delta$-t ellenkező irányban változtatva ugyanazokon a helyzeteken keresztül visszafele haladnánk, tehát ilyen módon a mechanizmus teljes ciklusát nem tudjuk feltérképezniehhez az algoritmust módosítani kellene, azonban a kitüzött cél a zérus sajátfrekvenciájú sajátmódok valósághü ábrázolása volt és erre az algoritmus ebben a formájában is megfelel.

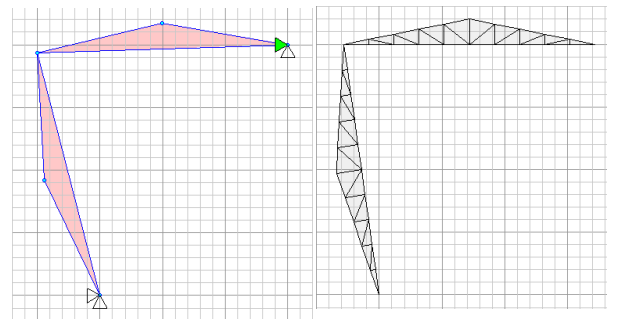

1. ábra. Egy szabadságfokú szerkezet sajátmódja, ahogyan az általunk kidolgozott módszerrel ábrázoltuk (balra), illetve ahogyan azt a klasszikus sajátmód-számitás visszaadja (jobbra). A szerkezet rögzitéséhez szükséges hiányzó kényszert a satírozott háromszög jelöli.

\section{Szakirodalmi hivatkozások}

[1] Norton, R., L.: An Introduction to the Synthesis and Analysis of Mechanisms and Machines. McGraw Hill, 2004.

[2] Avilés, R.; Navalpotro, S.; Amezua E.; Hernández, A.: An Energy-Based General Method for the Optimum Synthesis of Mechanisms. ASME, J. Mech. Des. 116(1), 127-136, 1994.

[3] Zienkiewicz, O., C.; Taylor, R., L.: The Finite Element Method: Its Basis and Fundamentals, Seventh Edition. Elsevier, 2013. 